\title{
A Calculation Method to Estimate the Thermodynamic Performance of Solar Tower Power Plants with an Open Air Brayton Cycle and a Combined Cycle
}

\author{
Vittorio Ferraro*, Valerio Marinelli, Jessica Settino, Francesco Nicoletti \\ Department of Mechanical, Energy and Management Engineering- DIMEG - Università della Calabria - 87036 Arcavacata di \\ Rende (CS), Italy
}

Corresponding Author Email: vittorio.ferraro@unical.it

https://doi.org/10.18280/ti-ijes.642-422

Received: 10 April 2020

Accepted: 3 May 2020

\section{Keywords:}

combined cycle, open air Brayton cycle, solar tower plants, thermodynamic performance

\begin{abstract}
In this study, a method will be described to evaluate the performance of two thermodynamic solar tower power plants of $50 \mathrm{MW}$. The first is an open air Brayton cycle, equipped with an inter-cooled compressor and a regenerator while the second consists in a BraytonRankine combined cycle. The annual performances of the two systems have been estimated, in terms of electricity, average annual efficiency of the heliostats field-receiver system, efficiency of the thermodynamic cycle and of the entire plant. The performances of the two plants have been compared to conventional plants using molten salts. The analysis carried out in this study shows that the technical performance of the combined cycle is superior to the Brayton cycle, and both systems have better performances than conventional solar tower systems using molten salts. The specific energy of the Brayton plant is $11.5 \%$ greater than that obtained for the plant using molten salts, while for the combined cycle there is an increase of $38.7 \%$ with respect to the system using molten salts.
\end{abstract}

\section{INTRODUCTION}

The interest in concentrating solar tower power plants is increasing worldwide $[1,2]$. The most common type of concentrating solar tower power plant is the one that uses molten salt as both heat transfer fluid and thermal storage medium. This plant is provided with a salt-water steam generator that feeds the power block operating with a water steam Rankine cycle [3, 4].

The first solar tower power plant built in the world was the $1 \mathrm{MW}$ water-steam experimental plant Eurelios [5], located in Adrano, Sicily (Italy), connected to the grid in 1981, followed in 1982 by the USA Solar One $10 \mathrm{MW}$ water-steam plant [6]. Solar One was converted in the 1990s' in the Solar Two plant [6], which employed a molten salt receiver and was provided with a molten salts heat storage.

Subsequently, the Spanish plants Planta Solar 10 [7, 8], in operation since 2007 and Planta Solar 20 [7, 8], in operation since 2009, respectively of $11 \mathrm{MW}$ and $20 \mathrm{MW}$ were built. These plants use water steam as heat transfer fluid, with a small storage unit that provides an autonomy of 1 hour.

Since 2008, the Julich Solar Tower plant [7, 9] of 1.5 MW, employing air as heat transfer fluid, has been operating in Germany. The air is heated up to $680{ }^{\circ} \mathrm{C}$ in the receiver, and sent to a steam generator that feeds the steam turbine. The receiver is equipped with a mass of ceramic material for heat storage, with an autonomy of 1.5 hours.

Since 2009, the 5 MW Sierra Sun Tower facility [7] has been operating in the USA, with water-steam fluid at temperatures of $218-440{ }^{\circ} \mathrm{C}$ and without heat storage.

Since 2011, also in Spain, the 19.9 MW Gemasolar Thermosolar Plant [7], has been active, employing molten salts as heat transfer fluid as well as storage medium, with inlet and outlet temperatures for the receiver of $290^{\circ} \mathrm{C}$ and $565^{\circ} \mathrm{C}$. The storage of heat is attained by two tanks, the hot tank and the cold tank, operating at $565^{\circ} \mathrm{C}$ and at $290{ }^{\circ} \mathrm{C}$, with an autonomy of 15 hours. A water-molten salts steam generator feeds the steam turbine of a Rankine cycle.

In California (USA), the Ivanpah facility [7, 10], the biggest in the world, has been in operation since 2014 , consisting of a group of three independent systems of 126, 133 and $133 \mathrm{MW}$, for a total of $392 \mathrm{MW}$, employing the molten salt as heat transfer fluid, with inlet and outlet temperatures of 249 and $565^{\circ} \mathrm{C}$, without heat storage, and a steam generator that feeds the Rankine cycle.

In USA, Nevada, the $110 \mathrm{MW}$ Tonopah facility [7] has been operating since 2015 . It uses molten salts as heat transfer fluid (at temperatures of $288^{\circ} \mathrm{C}$ and $565^{\circ} \mathrm{C}$ ) and the storage unit ensures an autonomy of 10 hours.

In South Africa, the $50 \mathrm{MW}$ Khi Solar One plant [7] has been in operation since 2016, with water-steam as heat transfer fluid, and a storage of 2 hours.

In China, the $110 \mathrm{MW}$ Atacama1 [7] system uses molten salts, at temperatures of 300 and $550^{\circ} \mathrm{C}$, and the storage system has an autonomy of 10 hours. It is worth mentioning two plants in China: the $200 \mathrm{MW}$ Golmud plant [7], using molten salts, with a storage of 15 hours and the 50 MW SUPCON Solar Project plant [7], using molten salts, with a storage of 6 hours.

In Morocco the $150 \mathrm{MW}$ NOOR III plant [7] uses molten salts with an autonomy of the storage unit of 8 hours.

For some years there has been an increasing interest in the possible use of gases, including helium, neon, argon, carbon dioxide, nitrogen, air, as heat transfer fluids in solar receivers. Gases have lower densities than liquids and therefore they present higher pressure drops and higher pumping powers than those of molten salts. It is possible to overcome this 
disadvantage by increasing the gas operating pressure. At Plataforma Solar de Almeria (PSA), pressure drops and pumping power measurements for helium, nitrogen, carbon dioxide and air were carried out in an experimental setup consisting of two $50 \mathrm{~m}$ linear parabolic collectors connected in series or in parallel in a closed hydraulic circuit [11]. Owing to its excellent properties as heat transfer medium and because of its high density at high pressures, which reduces the pumping power, carbon dioxide under supercritical conditions (pressure greater than 73.86 bar) has proved to be the best gas to use in solar systems. In references [12-16] various studies are reported concerning the performance of solar systems, both with parabolic collectors as well as with solar towers, employing carbon dioxide under supercritical conditions, confirming the advantages offered by this fluid. However, using carbon dioxide, there is the possibility of formation of carbonic acid, which is corrosive for carbon steel pipes. For this reason, a strict control of the moisture content is required [11].

As an alternative to carbon dioxide, the use of atmospheric air as heat transfer fluid, evolving in a Brayton cycle or in a combined cycle, in plants with both parabolic trough collectors [17-19], and solar towers [20] has been proposed.

The advantages of air with respect to all other heat transfer fluids are very clear: air is inexpensive, completely safe, and non-pollutant; moreover, no water is required, which is a very attractive prospective in arid climates.

The first experiments with air were carried out at PSA in 2003 , by using a first prototype hybrid solar powered $230 \mathrm{~kW}$ gas turbine system. The solar receiver allowed to reach temperatures of $800{ }^{\circ} \mathrm{C}$ at the combustor air inlet [21]; then, other experiments were carried out in Newcastle, Australia, at the National Solar Energy Centre, where a $200 \mathrm{~kW}$ demonstration hybrid system with air Brayton cycle was constructed by the CSIRO agency [22-24]; moreover, the Abengoa Solar Company is performing experimental analysis on an air hybrid Brayton plant of $4.5 \mathrm{MW}[25,26]$, provided with a $65 \mathrm{~m}$ tower and a receiver in which the air is heated up to $800{ }^{\circ} \mathrm{C}$ at Abengoa's Solúcar Platform near Seville.

The scientific literature on concentrating solar tower power plants operating with an open air Brayton cycle is still scarce, while there are few papers analysing the performance of airwater combined cycle solar tower systems [27-29].

This work aims at filling this gap. The thermodynamic performances of a solar tower power plant with an open air Brayton cycle plant (B plant) and a combined cycle have been analysed.

A methodology to evaluate their hourly and annual performance has been developed for both plants. The plants here considered are not equipped with a heat storage unit, which can consist of a rock-based packed-bed system. This aspect is beyond the scope of the work and will be analysed in future studies.

Moreover, the performance of a reference tower solar plant with molten salts has been evaluated, and compared to the proposed solar tower power plants.

\section{CALCULATION METHOD}

Figure 1 schematically shows the concentrating solar tower power plant with an open air Brayton cycle. It consists of an inter-refrigerated multistage compressor and a regenerator. The air drawn from the atmosphere is compressed by a three inter-cooled stadiums compressor, preheated in the regenerator and sent into the receiver placed on top of the solar tower, from which it exits at high temperature. Afterwards, it is sent to the gas turbine connected to the electric generator, and before being discharged to the atmosphere, the air passes through the regenerator. A cooling tower is used to refrigerate the water used in the cooling circuit.

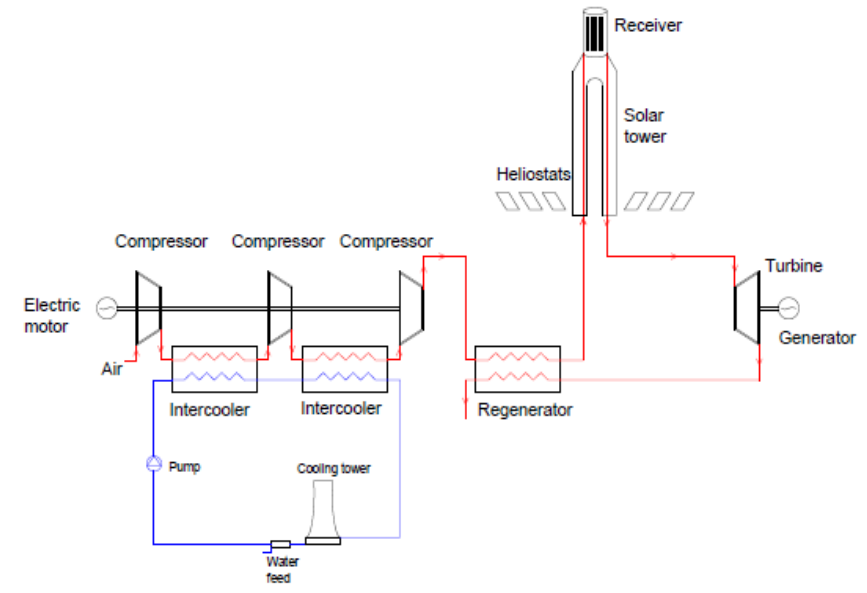

Figure 1. Scheme of a solar tower power plant with an open air Brayton cycle

Figure 2 refers to the combined cycle. It consists of a topping Brayton cycle, a heat recovery boiler and a bottoming Rankine cycle. The compressor sends the air directly into the receiver. The air at high temperatures drives the gas turbine. Afterwards, it is sent to a heat recovery steam generator, where superheated steam is produced and used to drive the steam turbine.

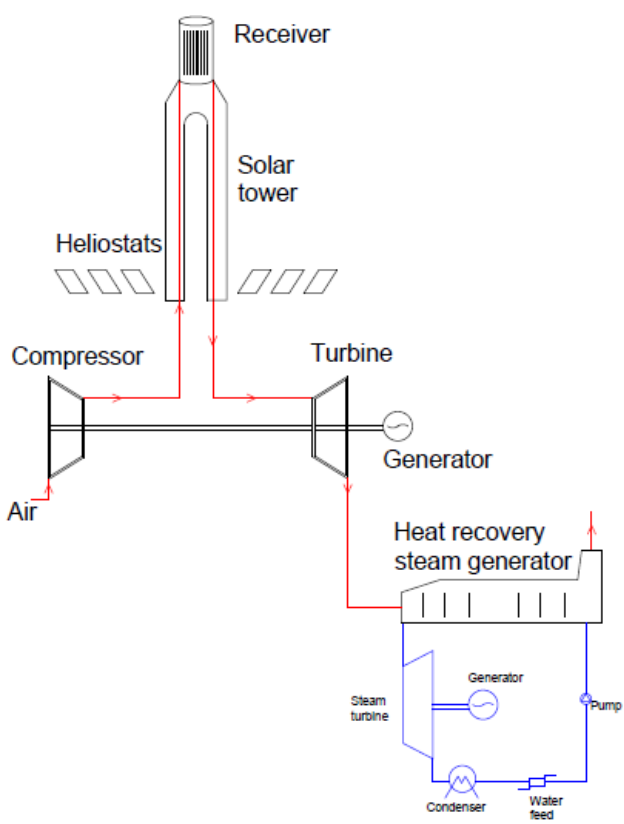

Figure 2. Scheme of the Brayton-Rankine combined cycle plant

In both systems, a constant turbine inlet temperature (TIT) equal to $1000^{\circ} \mathrm{C}$ is considered, while the flow rate varies depending on the direct normal radiation (DNI). In any case, the air flow rate should not be lower than $60 \%$ of its nominal 
design value, in order to not degrade excessively the isentropic efficiency of the compressor. When the flow rate reaches its minimum value, it is kept constant as the DNI decreases. This determines a reduction of the turbine inlet temperature, up to a minimum value to $600^{\circ} \mathrm{C}$, for which the plant can still produce electricity.

The operation of the components of the two systems was simulated by the THERMOFLEX code [30], starting from the design conditions, see table 1 and table 5 and then evaluating their performances in off-design conditions, by varying the inlet temperature of the air and the opening of the Inlet Guide Vanes (IGV) of the compressor, so as to vary the air flow rate.

Based on the results obtained, some correlations have been developed for the key variables, such as the air temperature at the compressor exit in the combined cycle plant (or at the regenerator exit in the Brayton cycle) and the thermodynamic efficiency of the gas and steam turbines in the combined cycle (or of the gas turbine in the Brayton cycle).

At low solar irradiance, the plants are operated at constant flow rate, the correlations developed concerned the thermal power transferred to the fluid in the receiver, the air temperature at the inlet of the turbine, and the thermodynamic efficiency of the turbines.

All these correlations, along with a simulation model of the heliostat field and the tower receiver, were implemented in a Matlab calculation algorithm, called TERSOLTO (thermodynamic solar tower) in the $\mathrm{B}$ and $\mathrm{CC}$ versions, respectively valid for the Brayton cycle and the combined cycle.

Through TERSOLTO, starting from the values of direct solar irradiance, air temperature and humidity, the hourly values of the electrical power generated by the plants, the average hourly and annual values of the efficiency and the electricity produced in a year can be calculated.

In the following paragraphs the models and correlations used are described in detail.

\subsection{Calculation model of the Brayton Cycle}

Table 1 reports the plant design data. The main input data are: the rated electrical power, the atmospheric air temperature, the DNI design value, the inlet temperature to the gas turbine, the pressure ratio of the compressor and the turbine.

Once defined the type of system and characteristics of the various components, the THERMOFLEX code considers the receiver as a generic heat generator, and allows to calculate the nominal air flow rate. Hence, it is possible to obtain the desired net electrical power, the thermal power supplied from the receiver to the fluid, the gross and net electrical power supplied from the gas turbine, the net thermodynamic efficiency of the cycle and many other variables of interest.

By means of the THERMOFLEX code, after determining the above mentioned variables in design conditions, calculations in off-design conditions were performed, considering: three different values of the atmospheric air temperature of $0^{\circ} \mathrm{C}, 25^{\circ} \mathrm{C}$ and $50^{\circ} \mathrm{C}$; three opening values of the IGV, of $100 \%, 80 \%$ and $60 \%$; and maintaining the turbine inlet temperature constant at $1000^{\circ} \mathrm{C}$.

Table 2 reports the values of air flow rate, air temperature at the regenerator exit, the heat transferred from the receiver to the fluid, the net efficiency of the power block and the net electrical power plant production, for different outside air temperatures and IGV.
Table 1. Design data of Air Brayton Solar Tower Power Plant located in Almeria

\begin{tabular}{cc}
\hline Parameter & Value \\
\hline Nominal net electrical Power & $50 \mathrm{MW}$ \\
Direct Normal Irradiance (DNI) & $850 \mathrm{~W} / \mathrm{m}^{2}$ \\
Zenith angle & $13.850^{\circ}$ \\
Azimuth angle & $-10.713^{\circ}$ \\
Total area of heliostats & $302,499 \mathrm{~m}^{2}$ \\
Reflectivity of heliostats & 0.94 \\
Absorptivity of receiver & 0.97 \\
Optical efficiency of heliostats field & 0.567 \\
Efficiency of receiver & 0.850 \\
Tower height & $102.5 \mathrm{~m}$ \\
Compressor pressure ratio & 12.5 \\
Turbine pressure ratio & 8.5 \\
Net thermodynamic efficiency & 0.404 \\
Atmospheric air temperature $\left(\mathrm{T}_{\mathrm{A}}\right)$ & $25^{\circ} \mathrm{C}$ \\
Gas Turbine Inlet air temperature $(\mathrm{TIT})$ & $1000^{\circ} \mathrm{C}$ \\
Mass flow rate & $213 \mathrm{~kg} / \mathrm{s}$ \\
\hline
\end{tabular}

Table 2. Influence of IGV aperture and of inlet air temperature on the performance of the Brayton cycle plant

\begin{tabular}{ccccccc}
\hline $\begin{array}{c}\mathbf{T}_{\mathbf{A}} \\
\left({ }^{\circ} \mathbf{C}\right)\end{array}$ & $\begin{array}{c}\mathbf{I G V} \\
(\mathbf{\%})\end{array}$ & $\begin{array}{c}\mathbf{m} \\
(\mathbf{k g} / \mathbf{s})\end{array}$ & $\begin{array}{c}\mathbf{T} \\
\left({ }^{\mathbf{C}} \mathbf{C}\right)\end{array}$ & $\begin{array}{c}\mathbf{Q} \\
(\mathbf{M W})\end{array}$ & $\boldsymbol{\eta}_{\boldsymbol{P B}}$ & $\begin{array}{c}\boldsymbol{P}_{\boldsymbol{e l}} \\
(\mathbf{M W})\end{array}$ \\
\hline 0 & 100 & 229 & 477 & 135 & 0.414 & 56 \\
\hline 0 & 80 & 183 & 496 & 105 & 0.398 & 42 \\
\hline 0 & 60 & 138 & 518 & 76 & 0.457 & 27 \\
\hline 25 & 100 & 210 & 491 & 123 & 0.404 & 50 \\
\hline 25 & 80 & 168 & 508 & 95 & 0.389 & 37 \\
\hline 25 & 60 & 126 & 530 & 68 & 0.345 & 24 \\
\hline 50 & 100 & 194 & 503 & 111 & 0.387 & 43 \\
\hline 50 & 80 & 155 & 519 & 86 & 0.373 & 32 \\
\hline 50 & 60 & 116 & 541 & 62 & 0.327 & 20 \\
\hline
\end{tabular}

Using the values shown in Table 2, by means of the DataFit program developed by Oakdale Engineering [31], correlations for the air temperature at the regenerator exit $\mathrm{T}_{\text {or }}$ and of the net efficiency of the gas turbine $\eta_{g t}$, as functions of a parameter $\mathrm{x}$ were developed; $x$ is defined as the ratio between the air mass flow rate in the actual conditions and the nominal mass flow rate.

The correlations obtained are the following: for $\mathrm{T}_{\mathrm{A}}=0^{\circ} \mathrm{C}$,

$$
T_{o r}=a+b \cdot x^{3}+c / x
$$

with $\mathrm{a}=459.561 ; \mathrm{b}=-12.78871 ; \mathrm{c}=43.25952$

$$
\eta_{g t}=a+b \cdot x+c x^{0.5}
$$

with $\mathrm{a}=-0.49634 ; \mathrm{b}=-0.85800 ; \mathrm{c}=1.7696$

for $\mathrm{T}_{\mathrm{A}}=25^{\circ} \mathrm{C}$,

$$
T_{\text {or }}=a+b \cdot x^{3}+c / x^{1.5}
$$

with $\mathrm{a}=486.42211 ; \mathrm{b}=-17.80170 ; \mathrm{c}=22.19127$

$$
\eta_{g t}=a+b \cdot x+c x^{0.5}
$$

with $\mathrm{a}=-0.550466 ; \mathrm{b}=-0.895711 ; \mathrm{c}=1.85013$

for $\mathrm{T}_{\mathrm{A}}=50^{\circ} \mathrm{C}$,

$$
T_{o r}=a+b \cdot x^{3}+c / x
$$


with $\mathrm{a}=462.57941 ; \mathrm{b}=-13.297368 ; \mathrm{c}=43.1433$

$$
\eta_{g t}=a+b \cdot x+c \cdot x^{0.5}
$$

with $a=-0.61494 ; b=-0.94732 ; c=1.94717$

The proposed correlations present a correlation index of $99.99 \%$ and a maximum error of less than $0.5 \%$.

They have been implemented in the TERSOLTO-B algorithm, in which meteorological data of the sites where the plants are located (outside air temperature, relative humidity, DNI, etc.) are available. At any time, the flow rate value (m), which ensures an outlet temperature of the receiver of $1000^{\circ} \mathrm{C}$, can be obtained, using the heat balance equation between the solar thermal power supplied by the field of heliostats and the heat received by the fluid in the receiver, with an iterative method.

The balance equation is:

$$
\mathrm{SM} \mathrm{A}_{e} \mathrm{DNI} \eta_{o p t}-P_{\text {loss }}=\mathrm{m}\left(\mathrm{H}\left(\mathrm{T}_{o R}\right)-\mathrm{H}\left(T_{o r}\right)\right)
$$

where $\mathrm{SM}$ is the solar multiple, $\mathrm{A}_{\mathrm{e}}$ is the total area of the heliostats, $\eta_{\text {opt }}[32]$ is the optical efficiency of the heliostats field, taking into account the reflection coefficient of the mirrors, the transmissivity of the atmosphere, the cosine, shadowing, blocking, and spillage effects of the individual heliostats and the absorption coefficient of the receiver, $\mathrm{P}_{\text {loss }}$ is the sum of the radiative and the convection losses of the receiver, $m$ is the fluid flow rate, $\mathrm{H}\left(\mathrm{T}_{\mathrm{OR}}\right)$ is the enthalpy of the fluid at the outlet of the receiver and $\mathrm{H}\left(\mathrm{T}_{\mathrm{or}}\right)$ is the enthalpy of the fluid at the outlet of the regenerator.

The radiative loss $\mathrm{P}_{\text {loss }}$ was evaluated by the equation:

$$
P_{\text {rad }}=A_{R} \varepsilon_{R} \sigma\left(T_{R}^{4}-T_{A}^{4}\right)
$$

where, $A_{R}$ is the area of the receiver, $\varepsilon_{R}$ is the emissivity of the receiver, $\sigma$ is the Stephan-Boltzmann constant, $T_{R}$ is the temperature of the receiver and $T_{A}$ is the temperature of atmospheric air. For simplicity, it is assumed that the temperature of the receiver is uniform and equal to the turbine inlet temperature.

The convective loss is instead calculated using the equation:

$$
P_{\text {conv }}=h A_{R}\left(T_{R}-T_{A}\right)
$$

where, $h$ is the convective heat transfer coefficient between the receiver and the outside air. Normally, for high temperatures of the receiver, the convective loss is negligible compared to the radiative one.

Starting from the initial value of $x=1$ (valid in design conditions), at the considered hour, for the outside air temperature value an initial value of the outlet temperature from the regenerator is calculated by interpolation, using Eqns. (1), (3) and (5). Considering the quality of moist air, the enthalpies $\mathrm{H}\left(\mathrm{T}_{\mathrm{OR}}\right)$ and $\mathrm{H}\left(\mathrm{T}_{\mathrm{or}}\right)$ are calculated and, by Eq. (7), an initial value for the air flow rate and the parameter $\mathrm{x}$ are obtained. This procedure is repeated until $\mathrm{x}$ reaches convergence and for the final value of $\mathrm{x}$ the gas turbine efficiency and the electrical power delivered by the plant are calculated.

When the thermal power transmitted from the receiver to the Power Block is larger than $136 \mathrm{MW}, 10 \%$ higher than the nominal design value, part of heliostats is supposed to defocus, so as not to exceed this maximum power value. Hence, the maximum value of the dimensionless parameter $\mathrm{x}$ is 1.1 .
When the $\mathrm{x}$ value is lower than $0.6(60 \%$ of the nominal flow rate), for low values of DNI, it is assumed, as already stated, that the flow rate is kept constant, and the plant operates with a variable TIT up to a minimum value of $600^{\circ} \mathrm{C}$.

To determine the TIT under these conditions, a further series of calculations were carried out by THERMOFLEX code, maintaining the fluid flow rate constant and varying the TIT between $1000^{\circ} \mathrm{C}$ and $600^{\circ} \mathrm{C}$. From the data obtained, the following correlations for the TIT (Q) and the gas turbine efficiency $\eta_{g t}$ (TIT) were developed:

for $\mathrm{T}_{\mathrm{A}}=0^{\circ} \mathrm{C}$,

$$
T I T=a+b \cdot Q^{0.5}+c / Q
$$

with $a=317.763 ; b=82.5716 ; c=203.540$

$$
\eta_{g t}=a+b \cdot T_{I T}^{0.5}+c / T^{2}
$$

with $\mathrm{a}=0.63151 ; \mathrm{b}=-2.70358 \cdot 10^{-3} ; \mathrm{c}=-187992.161$; for $\mathrm{T}_{\mathrm{A}}=25^{\circ} \mathrm{C}$,

$$
T I T=a+b \cdot Q^{0.5}+c / Q
$$

with $\mathrm{a}=318.95934 ; \mathrm{b}=82.03883 ; \mathrm{c}=198.48652$

$$
\eta_{g t}=a \cdot T I T^{3}+b \cdot T I T^{2}+c \cdot T I T+d
$$

with $\quad \mathrm{a}=3.7425 \cdot 10^{-9} ; \quad \mathrm{b}=-1.0478 \cdot 10^{-5} ; \quad \mathrm{c}=1.0245 \cdot 10^{-2} ; \quad \mathrm{d}=-$ 3.1633

for $\mathrm{T}_{\mathrm{A}}=50^{\circ} \mathrm{C}$,

$$
T I T=a+\mathrm{b} \cdot Q^{0.5}+c / Q
$$

with $\mathrm{a}=317.92342 ; \mathrm{b}=82.0407 ; \mathrm{c}=209.2899$;

$$
\eta_{g t}=a+b \cdot T I T^{0.5}+c / T I T^{2}
$$

with $\mathrm{a}=0.458811 ; \mathrm{b}=3.118367 \cdot 10^{-11} ; \mathrm{c}=209.2899$

In the above equations $\mathrm{Q}$ is the thermal power transferred to the fluid in the receiver.

All correlations present a correlation index of $99.99 \%$ and a maximum error of less than $0.5 \%$.

The calculation of the total area of the heliostats $A_{e}$, of the height of the tower, of the size of the receiver, of the average optical efficiency of the heliostats $\eta_{\text {opt }}$, see Eq. (7), has been carried out by the DELSOL-3 code [33], assuming a configuration of the Surround-field type and an outer cylindrical receiver, using an optimization procedure of the field-receiver system performance. For the value of $\mathrm{SM}=1$, in the design conditions, summarized in Table 1, the following values were obtained: an area of the heliostats field of 302,499 $\mathrm{m}^{2}$, a tower height of $102.5 \mathrm{~m}$, a $6.615 \mathrm{~m}$ receiver diameter and a receiver height of $8.818 \mathrm{~m}$.

The values of the optical efficiency, calculated by DELSOL-3 code for SM 1.2, as a function of the zenith and azimuth angle of the sun, are given in Table 3 .

The optical performance of heliostats can be evaluated at any time of the day and month for interpolation. This calculation is made by the TERSOLTO program.

Figures 3-5 show, for the same value of the solar multiple, for a clear day in June and an intermediate day in December, the time trends of DNI, of optical efficiency of the heliostats field and of net electrical power. 
Table 3. Optical efficiency of the solar field of the Brayton Cycle Plant for SM=1.2 as a function of sun zenith and azimuth angles

\begin{tabular}{cccccccccc}
\hline & 0.5 & 7 & 15 & 30 & 45 & 60 & 75 & 85 & 90 \\
\hline 0 & 0.644 & 0.654 & 0.662 & 0.674 & 0.676 & 0.656 & 0.539 & 0.304 & 0.220 \\
30 & 0.644 & 0.652 & 0.659 & 0.666 & 0.665 & 0.642 & 0.525 & 0.286 & 0.205 \\
60 & 0.644 & 0.648 & 0.649 & 0.646 & 0.634 & 0.603 & 0.483 & 0.262 & 0.186 \\
90 & 0.644 & 0.642 & 0.636 & 0.619 & 0.595 & 0.552 & 0.431 & 0.237 & 0.172 \\
120 & 0.643 & 0.635 & 0.622 & 0.592 & 0.557 & 0.506 & 0.39 & 0.222 & 0.167 \\
150 & 0.643 & 0.631 & 0.613 & 0.574 & 0.53 & 0.473 & 0.36 & 0.205 & 0.157 \\
180 & 0.643 & 0.629 & 0.609 & 0.567 & 0.521 & 0.462 & 0.347 & 0.194 & 0.148 \\
210 & 0.643 & 0.631 & 0.613 & 0.574 & 0.531 & 0.474 & 0.361 & 0.206 & 0.158 \\
240 & 0.643 & 0.636 & 0.623 & 0.593 & 0.558 & 0.508 & 0.391 & 0.226 & 0.174 \\
270 & 0.644 & 0.642 & 0.636 & 0.62 & 0.596 & 0.554 & 0.434 & 0.25 & 0.191 \\
300 & 0.644 & 0.648 & 0.649 & 0.646 & 0.635 & 0.604 & 0.487 & 0.287 & 0.222 \\
330 & 0.644 & 0.652 & 0.659 & 0.666 & 0.665 & 0.642 & 0.528 & 0.309 & 0.235 \\
\hline
\end{tabular}

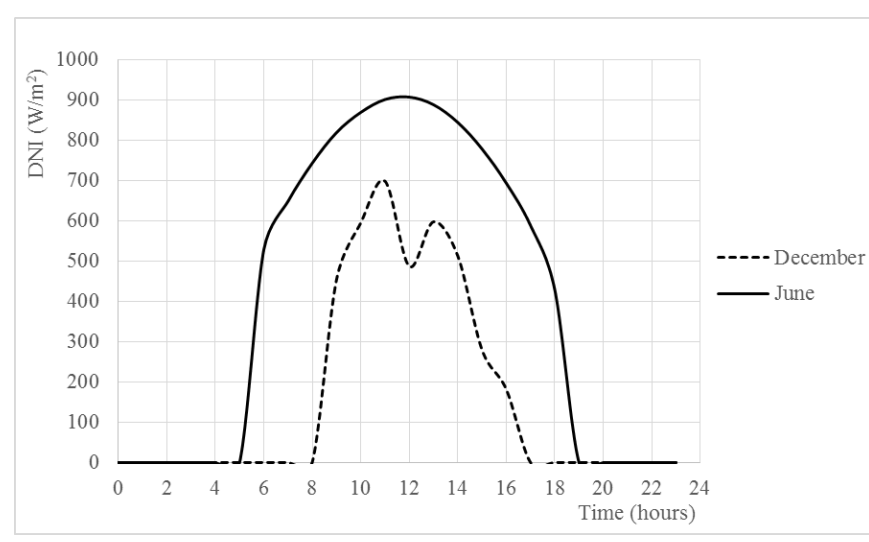

Figure 3. DNI as a function of time for a clear day in June and an intermediate day in December in Almeria

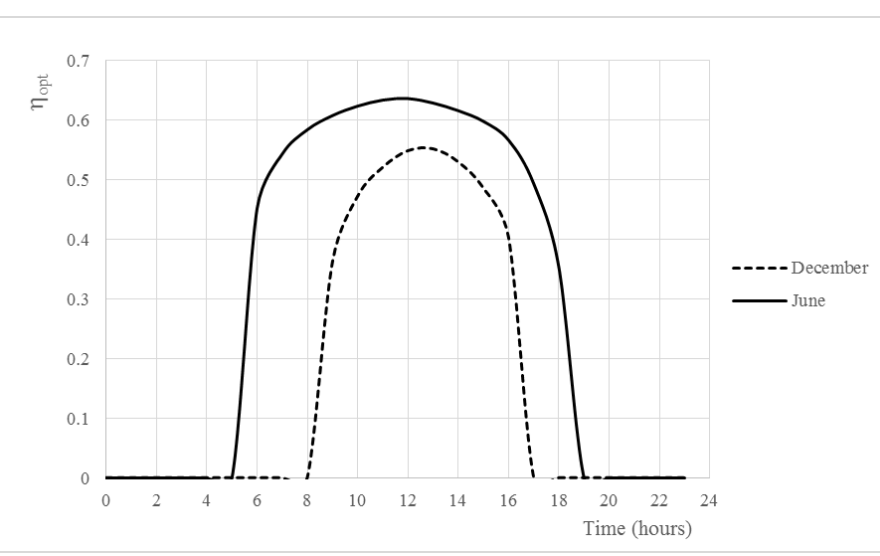

Figure 4. Heliostat optical efficiency as a function of the time in the Brayton Cycle

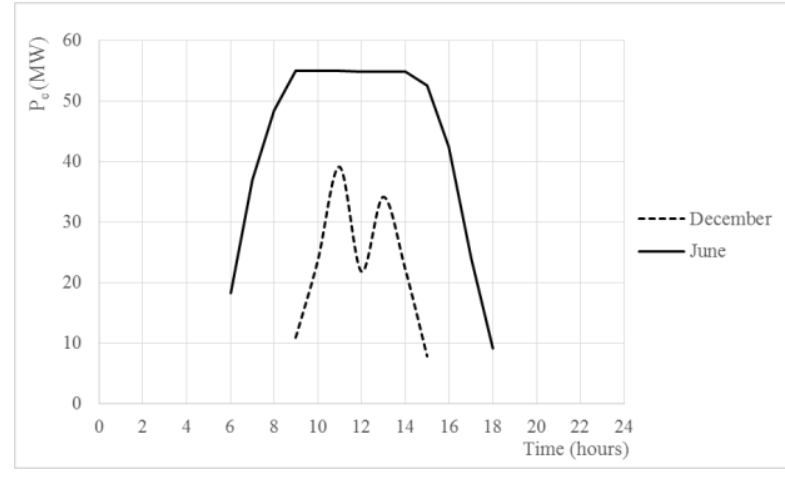

Figure 5. Electrical Power as a function of time in the Brayton Cycle plant
Table 4. Annual data of Brayton Cycle Plant

\begin{tabular}{ccccccc}
\hline $\mathrm{SM}$ & $\mathrm{E}_{\mathrm{el}}\left(\mathrm{MWh}_{\mathrm{el}}\right)$ & $\mathrm{Q}\left(\mathrm{MWh}_{\mathrm{t}}\right)$ & $\eta_{F R}$ & $\eta_{P B}$ & $\eta_{P}$ & $\begin{array}{c}\mathrm{CF} \\
(\%)\end{array}$ \\
\hline 1 & 83751 & 215063 & 0.349 & 0.389 & 0.135 & 19.1 \\
\hline 1.2 & 97943 & 247365 & 0.334 & 0.395 & 0.132 & 22.4 \\
\hline 1.4 & 107812 & 270034 & 0.313 & 0.399 & 0.124 & 24.6 \\
\hline 1.6 & 114535 & 285367 & 0.289 & 0.401 & 0.115 & 26.1 \\
\hline 1.8 & 118057 & 293556 & 0.264 & 0.402 & 0.106 & 27.1 \\
\hline 2.0 & 120297 & 298694 & 0.242 & 0.405 & 0.098 & 27.5 \\
\hline
\end{tabular}

Table 4 shows the annual electricity supplied from the plant, the annual thermal energy supplied to the fluid, the average annual efficiency of field-receiver system, the average efficiency of the power block, the global efficiency of the plant and the load factor CF (percentage of equivalent hours of working at nominal power compared to the total number of hours available in a year), as a function of solar multiple SM.

\subsection{Calculation model of the combined cycle}

Table 5 reports the design data of the solar tower power plant with a combined cycle.

Table 5. Design data of the Solar Tower Power Plant with Combined Cycle located in Almeria

\begin{tabular}{cc}
\hline Parameter & Value \\
\hline Nominal net electrical Power & $50 \mathrm{MW}$ \\
\hline Direct Normal Irradiance (DNI) & $850 \mathrm{~W} / \mathrm{m}^{2}$ \\
\hline Zenith angle & $13.850^{\circ}$ \\
\hline Azimuth angle & $-10.713^{\circ}$ \\
\hline Total area of heliostats & $273,784 \mathrm{~m}^{2}$ \\
\hline Reflectivity of heliostats & 0.94 \\
\hline Absorptivity of receiver & 0.97 \\
\hline Optical efficiency of heliostats field & 0.573 \\
\hline Efficiency of Receiver & 0.835 \\
\hline Tower height & $105 \mathrm{~m}$ \\
\hline Compressor pressure ratio & 12.5 \\
\hline Turbine pressure ratio & 8.5 \\
\hline Net thermodynamic efficiency & 0.449 \\
\hline Atmospheric air temperature $\left(\mathrm{T}_{\mathrm{A}}\right)$ & $25^{\circ} \mathrm{C}$ \\
\hline gas turbine Inlet air temperature $(\mathrm{TIT})$ & $1000{ }^{\circ} \mathrm{C}$ \\
\hline Mass flow rate & $156 \mathrm{~kg} / \mathrm{s}$ \\
\hline
\end{tabular}

Table 6 reports the values of the air flow rate $(\mathrm{m})$, of the air temperature at compressor outlet, of the thermal power(Q), of the gas turbine $\left(\eta_{g t}\right)$ and steam turbine efficiencies $\left(\eta_{s t}\right)$, of the net efficiency of the power block $\left(\eta_{P B}\right)$ and of the net electrical power output from the plant, for different outside air temperature and of IGV. 
Table 6. Influence of IGV aperture and of inlet air temperature on the performance of the CC plant

\begin{tabular}{ccccccccc}
\hline$T_{A}\left({ }^{\circ} \mathrm{C}\right)$ & $\begin{array}{c}\mathrm{IGV} \\
(\%)\end{array}$ & $\begin{array}{c}\mathrm{m} \\
(\mathrm{kg} / \mathrm{s})\end{array}$ & $\mathrm{T}\left({ }^{\circ} \mathrm{C}\right)$ & $\mathrm{Q}(\mathrm{MW})$ & $\eta_{g t}$ & $\eta_{s t}$ & $\eta_{P B}$ & $P_{e l}(\mathrm{MW})$ \\
\hline 0 & 100 & 168 & 359 & 122 & 0.275 & 0.167 & 0.442 & 53.8 \\
\hline 0 & 80 & 137 & 307 & 107 & 0.271 & 0.181 & 0.452 & 48.2 \\
\hline 0 & 60 & 103 & 272 & 84 & 0.229 & 0.207 & 0.436 & 37 \\
\hline 25 & 100 & 156 & 378 & 111 & 0.268 & 0.182 & 0.450 & 50 \\
\hline 25 & 80 & 125 & 335 & 95 & 0.253 & 0.200 & 0.453 & 43 \\
\hline 25 & 60 & 94 & 296 & 76 & 0.213 & 0.225 & 0.438 & 33 \\
\hline 50 & 100 & 139 & 389 & 101 & 0.256 & 0.203 & 0.460 & 46 \\
\hline 50 & 80 & 112 & 358 & 85 & 0.227 & 0.224 & 0.452 & 38 \\
\hline 50 & 60 & 84 & 330 & 67 & 0.174 & 0.251 & 0.426 & 28 \\
\hline
\end{tabular}

Table 7. Optical efficiency of the solar field of the Combined Cycle Plant for SM=1.2 as a function of sun zenith and azimuth angles

\begin{tabular}{cccccccccc}
\hline & 0.5 & 7 & 15 & 30 & 45 & 60 & 75 & 85 & 90 \\
\hline 0 & 0.641 & 0.641 & 0.649 & 0.655 & 0.661 & 0.658 & 0.635 & 0.521 & 0.305 \\
\hline 30 & 0.641 & 0.65 & 0.658 & 0.667 & 0.668 & 0.648 & 0.532 & 0.296 & 0.214 \\
\hline 60 & 0.641 & 0.648 & 0.654 & 0.66 & 0.657 & 0.633 & 0.518 & 0.288 & 0.211 \\
\hline 90 & 0.64 & 0.644 & 0.645 & 0.64 & 0.628 & 0.596 & 0.478 & 0.253 & 0.178 \\
\hline 120 & 0.64 & 0.638 & 0.633 & 0.615 & 0.59 & 0.548 & 0.428 & 0.238 & 0.175 \\
\hline 150 & 0.64 & 0.633 & 0.62 & 0.591 & 0.555 & 0.505 & 0.391 & 0.221 & 0.164 \\
\hline 180 & 0.639 & 0.629 & 0.612 & 0.574 & 0.531 & 0.475 & 0.362 & 0.205 & 0.156 \\
\hline 210 & 0.639 & 0.627 & 0.609 & 0.568 & 0.523 & 0.464 & 0.35 & 0.194 & 0.145 \\
\hline 240 & 0.639 & 0.629 & 0.612 & 0.575 & 0.533 & 0.477 & 0.364 & 0.207 & 0.157 \\
\hline 270 & 0.64 & 0.633 & 0.622 & 0.593 & 0.558 & 0.508 & 0.393 & 0.227 & 0.172 \\
\hline 300 & 0.64 & 0.639 & 0.634 & 0.617 & 0.593 & 0.551 & 0.432 & 0.249 & 0.191 \\
\hline 330 & 0.641 & 0.645 & 0.646 & 0.642 & 0.63 & 0.598 & 0.482 & 0.285 & 0.222 \\
\hline
\end{tabular}

By means of the THERMOFLEX code, the following correlations for the exit temperature from the compressor $\mathrm{T}_{\mathrm{oc}}$, for the gas turbine efficiency $\eta_{g t}$ and the steam turbine efficiency $\eta_{s t}$ have been developed, considering a variable air flow rate:

for $\mathrm{T}_{\mathrm{A}}=0^{\circ} \mathrm{C}$,

$$
T_{o c}=a+\mathrm{b} \cdot x^{3}
$$

with $a=246.5919 ; b=90.25454$;

$$
\eta_{g t}=a+b / x^{2}
$$

with $a=0.308604 ; b=-3.373074 \cdot 10^{-2}$

$$
\eta_{s t}=a+b / x
$$

with $a=0.103356 ; b=-6.824015 \cdot 10^{-2}$ for $\mathrm{T}_{\mathrm{A}}=25^{\circ} \mathrm{C}$,

$$
T_{o c}=a \cdot b^{x}
$$

with $a=204.3563 ; b=1.85103$;

$$
\eta_{g t}=a+b / x^{2}
$$

with $a=0.300301 ; b=-3.125406 \cdot 10^{-2}$;

$$
\eta_{s t}=a \cdot x^{b}
$$

with $\mathrm{a}=0.182133 ; \mathrm{b}=-0.414489$;

for $\mathrm{T}_{\mathrm{A}}=50^{\circ} \mathrm{C}$,

$$
T_{o c}=a \cdot b^{x}
$$

with $a=255.1888 ; b=1.60495$

$$
\eta_{g t}=a+b / x
$$

with $a=0.38281 ; b=-0.112634$

$$
\eta_{s t}=a \cdot b^{x}
$$

with $a=0.347898 ; b=-0.545025$

For a constant flow rate operation and variable TIT the following correlations were obtained: for $\mathrm{T}_{\mathrm{A}}=0^{\circ} \mathrm{C}$,

$$
T I T=a \cdot Q^{3}+\cdot Q^{2}+c \cdot Q+d
$$

with $\quad \mathrm{a}=5.898722 \cdot 10^{-5} ; \quad \mathrm{b}=-2.019249 \cdot 10^{-2} ; \quad \mathrm{c}=10.918839$; $\mathrm{d}=190.248464$

$$
\eta_{g t}=a+b \cdot T I T^{0.5}+c / T I T^{1.5}
$$

with $a=0.326549 ; b=-1.445094 \cdot 10^{-7} ; c=-3228.2688$;

$$
\eta_{s t}=a \cdot T I T^{3}+b \cdot T I T^{2}+c \cdot T I T+d
$$

with $\mathrm{a}=8.33333 \cdot 10^{-11} ; \mathrm{b}=-6.214285 \cdot 10^{-7} ; \mathrm{c}=10.918839 \cdot 10^{-3}$; $\mathrm{d}=-0.296885$

for $\mathrm{T}_{\mathrm{A}}=25^{\circ} \mathrm{C}$,

$$
T I T=a \cdot Q^{3}+b \cdot Q^{2}+c \cdot Q+d
$$

with $\quad \mathrm{a}=7.86633 \cdot 10-5 ; \quad \mathrm{b}=-2.38838 \cdot 10-2 ; \quad \mathrm{c}=11.733322$; $\mathrm{d}=214.908106$

$$
\eta_{g t}=a+b \cdot T I T+c / T^{1.5}
$$




$$
\eta_{s t}=a+b \cdot T I T^{2}+c \cdot T I T^{0.5}
$$

with $\mathrm{a}=-0.480034 ; \mathrm{b}=-1.443485 \cdot 10^{-7} ; \mathrm{c}=2.629234 \cdot 10^{-2}$ for $\mathrm{T}_{\mathrm{A}}=50^{\circ} \mathrm{C}$,

$$
T I T=a+b \cdot x^{0.5}+c / x^{0.5}
$$

with $a=-1013.990342 ; b=205.346943 ; c=2663.537571$

$$
\eta_{g t}=a+b \cdot T_{I T^{0.5}}+c / T_{I T}^{2}
$$

with $a=0.147127 ; b=3.3784093 \cdot 10^{-3} ; c=-66915.18$

$$
\eta_{s t}=a \cdot T I T^{2}+b \cdot T I T+c
$$

with $a=-0.0000003 ; b=-6.99999 \cdot 10^{-4} ; c=-0.149$

All above correlations present a correlation index of $99.99 \%$ and a maximum error less than $0.5 \%$.

The maximum thermal power transmitted from the receiver to the power block, in this plant, is $122 \mathrm{MW}$.

Using DELSOL-3 code, the total area of the heliostats $A_{e}$, for $\mathrm{SM}=1$, in the design conditions of Table 5, resulted to be $273,784 \mathrm{~m}^{2}$; the height of the tower and the size of the receiver resulted equal to those of the Brayton cycle plant.

The values of the optical efficiency, calculated by DELSOL-3 code for $\mathrm{SM}=1.2$, as a function of the zenith and azimuth angle of the sun, are given in Table 7 .

Figures 6-7 show the optical efficiency of the heliostats field and the net electrical power as functions of time for the same value of the solar multiple, for a clear day in June and an intermediate day in December.

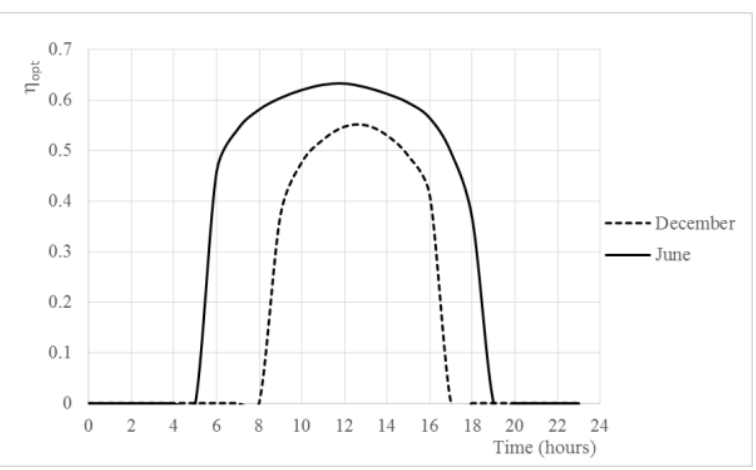

Figure 6. Heliostat optical efficiency as a function of time in the Combined Cycle plant

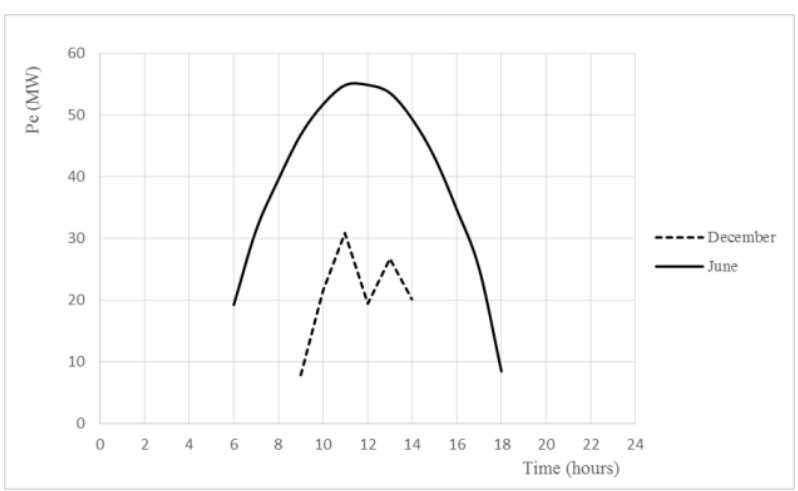

Figure 7. Electrical power as a function of time in the Combined Cycle plant

\begin{tabular}{ccccccc}
\hline SM & $\mathrm{E}_{\mathrm{el}}\left(\mathrm{MWh}_{\mathrm{el}}\right)$ & $\mathrm{Q}\left(\mathrm{MWh}_{\mathrm{t}}\right)$ & $\eta_{F R}$ & $\eta_{P B}$ & $\eta_{P}$ & $\begin{array}{c}\mathrm{CF} \\
(\%)\end{array}$ \\
\hline 1 & 95411 & 227627 & 0.419 & 0.408 & 0.171 & 21.7 \\
\hline 1.2 & 109538 & 253602 & 0.379 & 0.431 & 0.163 & 25.0 \\
\hline 1.4 & 121638 & 276993 & 0.355 & 0.439 & 0.156 & 27.7 \\
\hline 1.6 & 127156 & 287877 & 0.322 & 0.441 & 0.142 & 29.0 \\
\hline 1.8 & 134293 & 301372 & 0.300 & 0.445 & 0.134 & 30.6 \\
\hline 2.0 & 137408 & 306415 & 0.275 & 0.448 & 0.123 & 31.4 \\
\hline
\end{tabular}

Table 8 shows the annual electricity $\left(E_{\mathrm{el}}\right)$ supplied by the plant and the thermal energy (Q) supplied to the fluid, the average annual values of the field-receiver system efficiency $\left(\eta_{F R}\right)$, the efficiency of the power block $\left(\eta_{P B}\right)$, the global efficiency $\left(\eta_{P}\right)$ and the capacity factor CF as functions of the solar multiple SM.

\section{PERFORMANCE OF A REFERENCE MOLTEN SALTS PLANT}

It was considered useful to calculate the performance of a 50 MW solar plant with molten salts, accounted for by using the SAM code [34], in order to compare it to the two studied plants.

In design conditions, with minimum and maximum temperatures of the salts at $290^{\circ} \mathrm{C}$ and $565^{\circ} \mathrm{C}$, the heliostats area is $247,499 \mathrm{~m}^{2}$, the height of the tower $93.3 \mathrm{~m}$, the diameter of the receiver $8 \mathrm{~m}$ and its height $8.53 \mathrm{~m}$.

Table 9 shows the annual values of the electricity produced $\left(E_{\mathrm{el}}\right)$, the thermal energy $(\mathrm{Q})$ transferred to the fluid in the receiver, the receiver-field efficiency $\left(\eta_{F R}\right)$, the efficiency of the power block $\left(\eta_{P B}\right)$, the overall efficiency of the system $\left(\eta_{P}\right)$ and the capacity factor as functions of the solar multiple.

Table 9. Annual data of Molten Salts Plant

\begin{tabular}{ccccccc}
\hline SM & $E_{\mathrm{el}}(\mathrm{MWhel})$ & $\mathrm{Q}(\mathrm{MWh})$ & $\eta_{F R}$ & $\eta_{P B}$ & $\eta_{P}$ & $\begin{array}{c}\mathrm{CF} \\
(\%)\end{array}$ \\
\hline 1 & 61022 & 209000 & 0.415 & 0.292 & 0.121 & 13.9 \\
\hline 1.2 & 77424 & 253602 & 0.396 & 0.305 & 0.120 & 17.7 \\
\hline 1.4 & 88554 & 285000 & 0.385 & 0.310 & 0.119 & 20.2 \\
\hline 1.6 & 96011 & 305000 & 0.358 & 0.315 & 0.112 & 21.9 \\
\hline 1.8 & 101201 & 330000 & 0.345 & 0.306 & 0.105 & 23.1 \\
\hline 2.0 & 102255 & 330000 & 0.320 & 0.309 & 0.098 & 23.3 \\
\hline
\end{tabular}

\section{COMPARISON OF THE PLANTS}

Tables 1 and 2, containing the design data of the two systems, show that a $50 \mathrm{MW}$ electrical power plant can be obtained, in the case of the combined cycle, with a heliostats area of $273,784 \mathrm{~m}^{2}$, against an area of $302,499 \mathrm{~m}^{2}$ in the case of the Brayton cycle, with a reduction of $11 \%$.

This is mainly due to the difference between the thermodynamic net efficiency of the power block, which is 0.449 in the combined cycle and 0.404 in the Brayton cycle.

The annual electricity supplied by the combined cycle is $109,538 \mathrm{MWh}$, against a value of 97,943 MWh in the Brayton cycle, with an increase of about $12 \%$. The capacity factor is $25 \%$ in the combined cycle, compared with $22.4 \%$ of the Brayton cycle. The average annual plant efficiency is $16.3 \%$ in the combined cycle against the $13.2 \%$ of the Brayton cycle. 
The 50 MW plant using molten salts, with an area of heliostats of $247,497 \mathrm{~m}^{2}$ (lower than both the Brayton plant and the combined Brayton cycle for the smaller radiative losses from the receiver), provides an annual electrical energy, see table 9, of $61,022 \mathrm{MWh}$ for $\mathrm{SM}=1$.

Figure 8 shows the annual energy per square meter obtained with the three systems, as a function of the solar multiple: the graph shows that the maximum value is obtained for $\mathrm{SM}=1.2$ and is $0.282 \mathrm{MWH} / \mathrm{m}^{2}$ for the Brayton plant, 0.351 $\mathrm{MWh} / \mathrm{m}^{2}$ for the combined cycle plant and $0.253 \mathrm{MWH} / \mathrm{m}^{2}$ for the plant using molten salts. Therefore, the specific energy of the Brayton plant is $11.5 \%$ greater than that obtained for the plant using molten salts, while for the combined cycle there is an increase of $38.7 \%$ with respect to the system using molten salts.

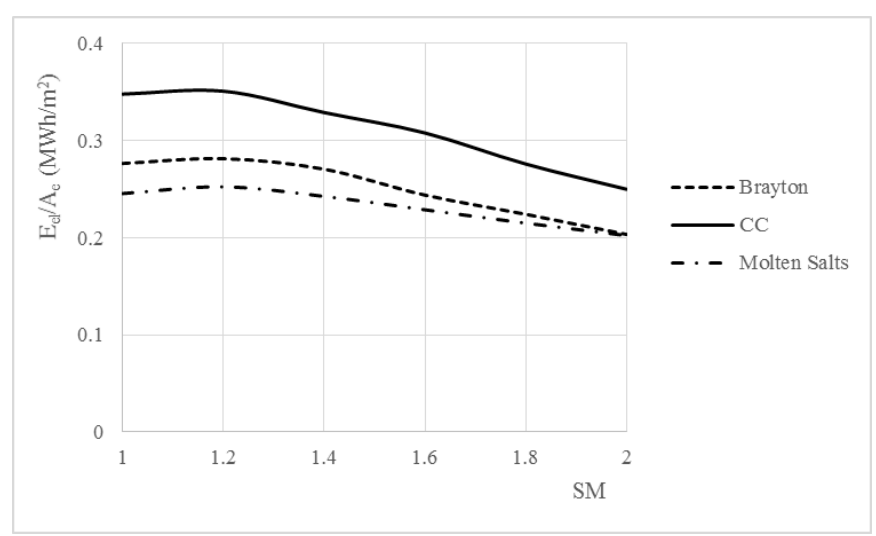

Figure 8. Annual Electrical Energy per square meter of heliostat as a function of solar multiple

Based on these results, it is evident that the technical performance of the combined cycle is superior to that of the Brayton cycle, and both of these systems have better performances than the plant using molten salts.

\section{CONCLUSIONS}

A calculation method was developed for the design and the estimation of the annual performance of two $50 \mathrm{MWe}$ concentrating solar tower power plants that use atmospheric air as heat transfer fluid. In the first plant the air evolves in an open Brayton cycle, with three inter-cooled compressor stages and a regenerator which preheats the air before it enters the solar energy receiver; the second plant is a combined cycle, provided at the exit of the gas turbine with a boiler to recover heat for the production of steam feeding the steam turbine.

The annual performance of the two systems has been estimated, in terms of electricity, average annual efficiency of the heliostats field-receiver system, efficiency of the thermodynamic cycle and of the entire plant, comparing these parameters with those of a plant with molten salts of the same nominal power output.

The technical performance of the two proposed systems is superior to molten salt systems, currently widely established on a global scale. In fact, the specific annual electrical energy (per square meter of heliostat) is, in the Brayton cycle, 11.5\% higher than that obtained with the system using molten salts, while in the combined cycle plant an increase of $38 \%$ was achieved.

\section{REFERENCES}

[1] Falcone, P.K. (1986). A handbook for solar central receiver design. SANDIA National Laboratories. https://doi.org/10.2172/6545992

[2] Romero-Alvarez, M. (2007). Concentrating Solar Thermal Power- Handbook of Energy Efficiency and Renewable Energy. Plataforma Solar de Almeria, CIEMAT.

[3] Rubbia, C. (2001). Solar Thermal Energy Production. Guidelines and future programs of ENEA, ENEA/TM/PRES/2001 07. Available at: Www.enea.it/com/ing; June 2001.

[4] Ortega, J.I., Burgaleta, J.I., Tellez, F. (2008). Central receiver system solar plant using molten salt as heat transfer fluid. Journal of Solar Energy Engineering, $130(2)$.

[5] Hofmann, J., Gretz, J. (1980). The 1 MW experimental solar power plant of the European Community. Electric Power Systems Research, 3(1-2): 13-24. https://doi.org/10.1016/0378-7796(80)90019-X

[6] www.cspworld.org/cspworldmap/solar-one-solar-two/

[7] NREL Concentrating Solar Power Projects http://www.nrel.gov/csp/solarpaces/

[8] http://www.abengoasolar.com/web/en/plantas_solares/p lantas_para_terceros/espana/

[9] Hennecke, K., Schwarzbozl, P., Koll, G., Beuter, M., Hoffschmidt, B., Gottsche, J., Hartz, T. (2007). The Solar Power Tower Jülich - A Solar Thermal Power Plant for Test and Demonstration of Air Receiver echnology. In: Proceedings of ISES World Congress, 1749-1753. https://doi.org/10.1007/978-3-540-75997-3_358

[10] Sullivan, R., Abplanalp, J., (2015). Visibility and Visual Characteristics of the Ivanpah Solar Electric Generating System Power Tower Facility. Argonne National Labory, Enviromental Science Division, March.

[11] Rodríguez-García, M., Payes, J.M.M., Biencinto, M., Adler, J.P., Diez Vallejo, L.E. (2009). First experimental results of a solar PTC facility using gas as the heat transfer fluid. In: Solar PACES Conference, Berlin, Germany.

[12] Chacartegui, R., Escalona, J.M.M., Sanchez, D., Monje, B., Sanchez, T. (2011). Alternative cycles based on carbon dioxide for central receiver solar power plants. Applied Thermal Engineering, 31(5): 872-879. https://doi.org/10.1016/j.applthermaleng.2010.11.008

[13] Al-Sulaiman, F.A., Atif, M. (2015). Performance comparison of different supercritical carbon dioxide Brayton Cycles integrated with a solar power tower. Energy, 82: 61-71. https://doi.org/10.1016/j.energy.2014.12.070

[14] Padilla, R.V., Soo Too, Y.C., Benito, R., Stein, W. (2015). Exergetic analysis of supercritical Brayton Cycles integrated with solar receivers. Applied Energy, 148: 348-365.

[15] Kumar, P., Srinivasan, K. (2016). Carbon dioxide based power generation in renewable energy systems. Applied Themal Engineering, 109: 831-840. https://doi.org/10.1016/j.applthermaleng.2016.06.082

[16] Passos, L.A., de Abreu, S.L., da Silva, A.K. (2017). Optimal scale of solar-trough powered plants operating with carbon dioxide. Applied Thermal Enineering, 124: 1203-1212.

https://doi.org/10.1016/j.applthermaleng.2017.06.004 
[17] Ferraro, V., Marinelli, V. (2012). An evaluation of thermodynamic solar plants with cylindrical parabolic collectors and air turbine engines with open JouleBrayton cycle. Energy, 44: 862-869. https://doi.org/10.1016/j.energy.2012.05.005

[18] Ferraro, V., Imineo, F., Marinelli, V. (2013). An improved model to evaluate thermodynamic solar plants with cylindrical parabolic collectors and air turbine engines in open Joule-Brayton cycle. Energy, 53: 323331. https://doi.org/10.1016/j.energy.2013.02.051

[19] Amelio, M., Ferraro, V., Marinelli, V., Summaria, A. (2014). An evaluation of the performance of an integrated combined solar plant provided with an airlinear parabolic collectors. Energy, 69: 742-748. https://doi.org/10.1016/j.energy.2014.03.068

[20] Rovense, F., Amelio, M., Ferraro, V., Scornaienchi, N.M. (2016). Analysis of a concentrating solar power tower operating with a close Joule Brayton cycle and thermal storage. International Journal of Heat and Technology, 34(3): 485-490. https://doi.org/10.18280/ijht.340319

[21] Heller, P., Pfander, M., Denk, T., Tellez, F., Valverde, A., Fernandez, J., Ring, A. (2006). Test and evaluation of a solar powered gas turbine system. Solar Energy, $80(10)$ : $1225-1230$ https://doi.org/10.1016/j.solener.2005.04.020

[22] http://www.csiro.au/en/Research/EF/Areas/Solar/Solarthermal/.

[23] Nakatani, H., Osada, T., Kobayashi, K., Watabe, M., Tagawa, M. (2012). Development of a concentrated solar power generation system with a hot-air turbine. Mitsubishi Heavy Industries Technical Review, 49(1): 15 .

[24] (2014). Solar Air Turbine Project Final report: Project results. Commonwealth Scientific Industrial Research Organisation.

[25] Quero, M., Korzynietz, R., Ebert, M., Jiménez, A.A., Río, A.D., Brioso, J.A. (2014). Solugas-Operation experience of the first solar hybrid gas turbine system at MW scale. Energy Procedia, 49: 1820-1830. https://doi.org/10.1016/j.egypro.2014.03.193

[26] Korzynietz, R., Brioso, J.A., del Río, A., Quero, M., Gallas, M, Uhlig, R., Ebert, M., Buck, R., Teraji, D. (2016). Solugas-Comprehensive analysis of the solar hybrid Brayton plant. Solar Energy, 135: 578-589. https://doi.org/10.1016/j.solener.2016.06.020

[27] Spelling, J., Favrat, D., Martin, A., Agsburger, G. (2012). Thermoeconomic optimization of a combined-cycle solar tower power plant. Energy, 41: 113-120. https://doi.org/10.1016/j.energy.2011.03.073

[28] Spelling, J., Laumert, B., Fransson, T. (2014). Advanced hybrid solar tower combined-cycle power plants. Energy Procedia, 41(1): 113-120. https://doi.org/10.1016/j.energy.2011.03.073

[29] Okoroigwe, E., Madhlopa, A. (2016). An integrated combined cycle system driven by a solar tower: A review.
Renewable and Sustainable Energy Reviews, 57: 337350. https://doi.org/10.1016/j.rser.2015.12.092

[30] (2013). Thermoflex Program, version. Thermoflow Inc. Southborough (USA).

[31] (2005). Datafit, version 8.1.69. Oakdale (USA): Oakdale Engineering.

[32] Eddhibi, F., Amara, M.B., Balghouthi, M., Guizani, A. (2015). Optical study of solar tower power plants. Tunisia-Japan Symposium: R\&D of Energy and Material Sciences IOP Publishing. Journal of Physics: Conference Series, 596: 28-30.

[33] WinDelsol 1.0 "Users Guide".

[34] Gilman, P. (2009). SAM version 3.0, Solar Advisor Model reference manual for CSP trough systems. Golden, Colorado, USA: National Renewable Energy Laboratory, July 2009.

\section{NOMENCLATURE}

A

$\mathrm{CF}$

DNI

E

$\mathrm{H}$

$\mathrm{h}$

$\mathrm{m}$

$P$

Q

SM

$\mathrm{T}$

TIT

$\mathrm{x}$

\section{Greek symbols}

$\varepsilon$

$\eta$

$\sigma$

\section{Subscripts}

A

con

el

gt

o

opt

$\mathrm{r}$

$\mathrm{rad}$

$\mathrm{R}$

st area, $\mathrm{m}^{2}$

capacity factor, -

direct normal irradiance, W. $\mathrm{m}^{-2}$

annual energy, MWh

enthalpy, $\mathrm{kJ} / \mathrm{kg}$

heat transfer coefficient, W. $\mathrm{m}^{-2} \cdot \mathrm{K}^{-1}$

mass flow rate, $\mathrm{kg} . \mathrm{s}^{-1}$

power, MW

thermal power, MW

solar multiple, -

temperature, ${ }^{\circ} \mathrm{C}$

turbine inlet temperature, ${ }^{\circ} \mathrm{C}$

dimensionless mass flow rate, -

emissivity, -

efficiency, -

Stephan Boltzman Constant, W/m² $\mathrm{K}^{4}$ air

compressor

convective

heliostat

electrical

gas turbine

outlet

optical

regenerator

radiative

receiver

steam turbine 